\title{
Linalool, a Piper aduncum essential oil component, has selective activity against Trypanosoma cruzi trypomastigote forms at $4^{\circ} \mathrm{C}$
}

\author{
Luz Helena Villamizar1, Maria das Graças Cardoso², Juliana de Andrade², \\ Maria Luisa Teixeira² ${ }^{2}$ Maurilio José Soares ${ }^{1 /+}$ \\ ${ }^{1}$ Fundação Oswaldo Cruz-Fiocruz, Instituto Carlos Chagas, Laboratório de Biologia Celular, Curitiba, PR, Brasil \\ ${ }^{2}$ Universidade Federal de Lavras, Departamento de Química, Lavras, MG, Brasil
}

\begin{abstract}
BACKGROUND Recent studies showed that essential oils from different pepper species (Piper spp.) have promising leishmanicidal and trypanocidal activities.
\end{abstract}

OBJECTIVES In search for natural compounds against Trypanosoma cruzi, different forms of the parasite were incubated for $24 \mathrm{~h}$ at $28^{\circ} \mathrm{C}$ or $4^{\circ} \mathrm{C}$ with Piper aduncum essential oil (PaEO) or its main constituents linalool and nerolidol.

METHODS PaEO chemical composition was obtained by GC-MS. Drug activity assays were based on cell counting, MTT data or infection index values. The effect of $P a \mathrm{EO}$ on the $T$. cruzi cell cycle and mitochondrial membrane potential was evaluated by flow cytometry.

FINDINGS $P a$ EO was effective against cell-derived $\left(\mathrm{IC}_{50} / 24 \mathrm{~h}: 2.8 \mu \mathrm{g} / \mathrm{mL}\right)$ and metacyclic $\left(\mathrm{IC}_{50} / 24 \mathrm{~h}: 12.1 \mu \mathrm{g} / \mathrm{mL}\right)$ trypomastigotes, as well as intracellular amastigotes $\left(\mathrm{IC}_{50} / 24 \mathrm{~h}: 9 \mu \mathrm{g} / \mathrm{mL}\right)$. At $4^{\circ} \mathrm{C}-$ the temperature of red blood cells (RBCs) storage in blood banks - cell-derived trypomastigotes were more sensitive to $P a \mathrm{EO}\left(\mathrm{IC}_{50} / 24 \mathrm{~h}=3.8 \mu \mathrm{g} / \mathrm{mL}\right)$ than to gentian violet $\left(\mathrm{IC}_{50} / 24 \mathrm{~h}=\right.$ $24.7 \mu \mathrm{g} / \mathrm{mL})$. Cytotoxicity assays using Vero cells $\left(37^{\circ} \mathrm{C}\right)$ and $\mathrm{RBCs}\left(4^{\circ} \mathrm{C}\right)$ showed that $\mathrm{PaEO}$ has increased selectivity for cellderived trypomastigotes. Flow cytometry analysis showed that $P a \mathrm{EO}$ does not affect the cell cycle of $T$. cruzi epimastigotes, but decreases their mitochondrial membrane potential. GC-MS data identified nerolidol and linalool as major components of $P$ aEO, and linalool had trypanocidal effect $\left(\mathrm{IC}_{50} / 24 \mathrm{~h}: 306 \mathrm{ng} / \mathrm{mL}\right)$ at $4^{\circ} \mathrm{C}$.

MAIN CONCLUSION The trypanocidal effect of $P a E O$ is likely due to the presence of linalool, which may represent an interesting candidate for use in the treatment of potentially contaminated RBCs bags at low temperature.

Key words: essential oil - linalool - Piper aduncum - Trypanosoma cruzi - trypanocidal activity

The protozoan Trypanosoma cruzi is the etiologic agent of Chagas disease, a neglected tropical illness that is endemic in 21 Latin American countries (WHO 2016), and has spread to five continents, mainly due to immigration (Schmunis \& Yadon 2010). Chagas disease has no effective treatment and affects about 7-8 million people worldwide (WHO 2016), with about five million of those in Brazil (Salomon 2012). T. cruzi transmission routes include contact with infected blood-sucking insects (Rassi et al. 2009), blood transfusion (Assal \& Corbi 2011), vertical transfer from mother to fetus (Jackson et al. 2009), organ and tissue transplantation (Fishman \& Rubin 1998, Schmunis \& Yadon 2010), contact with infected conjunctiva or oral mucosa (Giddings et al. 2006), and laboratory accidents (Herwaldt 2001).

Benznidazole (BZ) is the drug commonly used to treat individuals with Chagas disease (Rajão et al. 2014). Treatment with BZ has approximately $80 \%$ efficacy in the acute phase and $20 \%$ in the chronic phase of the dis-

doi: 10.1590/0074-02760160361

Financial support: CNPq, FAPEMIG, Fiocruz.

LHV had a scholarship from the Students Program/Post-Graduation

Agreement PEC-PG from CAPES/CNPq, Brazil.

+ Corresponding author: maurilio@fiocruz.br

Received 10 August 2016

Accepted 1 November 2016 ease (Rassi et al. 2009). The side effects of BZ - which include allergic dermatitis, paresthesia, thrombocytopenia and leucopenia - lead to treatment discontinuation in $7-13 \%$ of cases (Bern 2011). Despite decades of efforts to obtain less toxic, easily accessible (and relatively inexpensive) drugs against Chagas disease, no effective molecule or compound, whether natural or synthetic, has yet been identified that could replace BZ in the clinic, to improve the quality of life of affected patients (Romanha et al. 2010).

From the natural products currently tested against T. cruzi the most studied alternatives are of plant origin (Coura \& de Castro 2002). The trypanocidal activity of approximately 400 plants species (over 100 plant families) has been analysed in the last two decades (Izumi et al. 2012). Nevertheless, relatively few reports have assessed the anti-trypanocidal activity of essential oils (EOs) (Alviano et al. 2012), volatile and aromatic compounds produced (as secondary metabolites) by all plant organs. In plants, EOs function as antiseptics and biocides, protecting not only against pathogenic microorganisms but also against herbivores. Due to their pleasant odor and low toxicity profile, several EOs are widely used in perfumes, food products and herbal medicines (Bakkali et al. 2008). EOs, or their major constituents, represent promising candidates for the development of drugs against $T$. cruzi. A number of different EOs are active against $T$. cruzi and not appreciably toxic to mammalian cells (Borges et al. 2012). 
Peppers (Piper spp., Piperaceae) form a large genus of plants ( $>700$ species) widespread in tropical and subtropical regions of the world, and used in traditional medicine as analgesic, antiseptic and antimicrobial agents (Orjala et al. 1994, Xu \& Li 2011). Whole extracts or purified molecules derived from a variety of pepper species have activity against Leishmania and Trypanosoma, usually in the $10-20 \mu \mathrm{g} / \mathrm{mL}$ range (Lopes et al. 2008, Regasini et al. 2009, Garcia et al. 2013). Pepper EOs are also active against trypanosomatid parasites. Piper auritum EO inhibits the proliferation of promastigotes of Leishmania major, L. mexicana, L. braziliensis and L. donovani, with $\mathrm{IC}_{50}$ values (for $72 \mathrm{~h}$ treatments) between 12.8 and $63.3 \mu \mathrm{g} /$ $\mathrm{mL}$ (Monzote et al. 2010). Also P. hispidum EO showed promising results (high antileishmanial activity with low cytotoxicity, and a safety index of eight) when treating $L$. amazonensis-infected macrophages (Houël et al. 2015). The EO of $P$. cubeba was not active against $L$. amazonensis, but was effective against $T$. cruzi, with $\mathrm{IC}_{50}$ values of 45.5 and $87.9 \mu \mathrm{g} / \mathrm{mL}$, for trypomastigote and amastigote forms, respectively (Esperandim et al. 2013).

P. aduncum (common names: 'aperta-ruão', 'jaborandi-falso', 'pimento-de-macaco' and 'matico') is a tropical bush typical from Central and South America. In Brazil it is found naturally in the Amazon and Atlantic Forests. P. aduncum extracts inhibits the proliferation of T. cruzi epimastigotes in vitro, with $\mathrm{IC}_{50}$ concentrations lower than $20 \mu \mathrm{g} / \mathrm{mL}$ (Flores et al. 2009). Also, five chromenes isolated from $P$. aduncum have anti-proliferative activity against $T$. cruzi epimastigotes, with $\mathrm{IC}_{50}$ values of 2.82 $\mu \mathrm{M}$, after $72 \mathrm{~h}$ of treatment (Batista Jr et al. 2008), suggesting that the anti-trypanocidal activity of this plant should be analysed further. Despite the trypanocidal activity of $P$. aduncum extracts, no studies have yet tested the effect of $P$. aduncum EOs against $T$. cruzi.

Here, we analysed the trypanocidal effect of $P$. aduncum $\mathrm{EO}(\mathrm{Pa} \mathrm{EO})$ against different developmental forms of T. cruzi, in bioassays for $24 \mathrm{~h}$. Gas chromatographymass spectrometry (GC-MS) data identified nerolidol and linalool as the major components of this essential oil, and linalool had strong trypanocidal effect $\left(\mathrm{IC}_{50} / 24\right.$ h: $306 \mathrm{ng} / \mathrm{mL}$ ) at $4^{\circ} \mathrm{C}$. The promising trypanocidal effect of $\mathrm{PaEO}$ is likely due to the presence of linalool, which may be used as a lead for further drug development.

\section{MATERIALS AND METHODS}

Vero cells - Vero cells (ATCC CCL-81) were grown in RPMI-1640 medium with L-glutamine (Sigma Aldrich, St. Louis, MO, USA), supplemented with $5 \%$ fetal calf serum (FCS; Cultilab, Campinas, SP, Brazil), at $37^{\circ} \mathrm{C}$, and in a humidified $5 \% \mathrm{CO}_{2}$ atmosphere. For seeding, cell monolayers were washed twice with PBS ( $\mathrm{pH}$ 7.2), trypsinized and collected by centrifugation at $100 \mathrm{~g}$ for $2 \mathrm{~min}$.

Parasites - In this work, we used the T. cruzi clone Dm28c. Epimastigote forms were kept at $28^{\circ} \mathrm{C}$ in LIT medium supplemented with $10 \%$ inactivated FCS, with passages at every three days. For the experiments, parasites obtained from 72-h cultures were used.

To obtain cell-derived trypomastigotes, Vero cells were incubated with cell-derived trypomastigotes (1:10 ratio of cells to parasites) in $75 \mathrm{~cm}^{2}$ culture flasks containing $8 \mathrm{~mL}$ DMEM. After $4 \mathrm{~h}$ of interaction, non-internalised parasites were removed by rinsing with phosphate-buffered saline (PBS), new medium was added, and then changed to fresh medium every $24 \mathrm{~h}$. After $96 \mathrm{~h}$ of infection, trypomastigotes released into the supernatant were collected by centrifugation at $3000 \mathrm{~g}$ for $10 \mathrm{~min}$.

To obtain metacyclic trypomastigotes, culture epimastigotes in late logarithmic growth phase (five days) were subjected to nutritional stress as described previously (Contreras et al. 1985). Culture epimastigotes (5-7 x $10^{7}$ cells $/ \mathrm{mL}$ ) were collected by centrifugation at 7000 $g$ for $5 \mathrm{~min}$ at $10^{\circ} \mathrm{C}$, and resuspended in TAU medium (Triatomine Artificial Urine: $190 \mathrm{mM} \mathrm{NaCl}, 17 \mathrm{mM} \mathrm{KCl}$, $2 \mathrm{mM} \mathrm{MgCl}, 2 \mathrm{mM} \mathrm{CaCl}, 8 \mathrm{mM}$ phosphate buffer $\mathrm{pH}$ 6.0 ), at a concentration of $5 \times 10^{8}$ cells $/ \mathrm{mL}$. After incubation for $2 \mathrm{~h}$ at $28^{\circ} \mathrm{C}$ (nutritional stress), parasites were transferred to $25 \mathrm{~cm}^{2}$ flasks containing $5 \mathrm{~mL}$ TAU3AAG medium (TAU supplemented with $10 \mathrm{mM}$ L-proline, 50 $\mathrm{mM}$ sodium glutamate, $2 \mathrm{mM}$ sodium aspartate and 10 $\mathrm{mM}$ glucose), at a final concentration of $5 \times 10^{6}$ cells $/ \mathrm{mL}$. After $72 \mathrm{~h}$, metacyclic trypomastigotes in the supernatant ( $\sim 80 \%$ parasites) were collected by centrifugation and purified by passage through a DEAE-cellulose affinity column, equilibrated in PSG buffer $\left(47.47 \mathrm{mM} \mathrm{Na}_{2} \mathrm{HPO}_{4}, 2.5\right.$ $\mathrm{mM} \mathrm{NaH}{ }_{2} \mathrm{PO}_{4} \cdot \mathrm{H}_{2} 0,37.76 \mathrm{mM} \mathrm{NaCl}, 55.5 \mathrm{mM}$ glucose).

P. aduncum essential oil (PaEO) purification and chemical analysis - P. aduncum L. (matico) leaves were collected on March 2013 in the morning, with no rain, at the Medicinal Plants Garden of the Universidade Federal de Lavras (UFLA, MG, Brazil). P. aduncum EO was obtained by distillation in a Clevenger equipment, at the Department of Chemistry, Federal University of Lavras. Prior to use in experiments, $P a \mathrm{EO}$ was diluted to 100 $\mathrm{mg} / \mathrm{mL}$ in DMSO ( $\mathrm{PaEO}$ stock solution). Final DMSO concentrations in activity assays did not exceed $0.5 \%$. Both undiluted and diluted (stock) $\mathrm{PaEO}$ were kept at $4^{\circ} \mathrm{C}$, and in the dark.

$P a$ EO chemical analysis was performed in the Department of Chemistry of UFLA, in a GC-17A Shimadzu gas chromatograph coupled to a QP 5000 Shimadzu mass spectrometer, with a selective detector. The column used was of fused silica/bound type (DB5, 30m x $0.25 \mathrm{~mm})$, with helium $(1 \mathrm{~mL} / \mathrm{min})$ as the mobile-phase gas. The following analysis conditions were used: injection at $220^{\circ} \mathrm{C}$, detection at $240^{\circ} \mathrm{C}$; oven temperature between $40^{\circ} \mathrm{C}$ and $240^{\circ} \mathrm{C}$, with addition of $3^{\circ} \mathrm{C} / \mathrm{min}$; initial column pressure of $100.2 \mathrm{kPa} ; 1: 10$ split ratio and injected volume of $1 \mu \mathrm{L}$ (solutions at 1\% v/v) in dichloromethane. Mass spectra of each compound were compared with the Wiley 229 library database, and with the tabulated Kovats index.

Single drug activity assays on T. cruzi developmental forms - All experiments were performed in biological and technical triplicates. Incubations were performed for $24 \mathrm{~h}$ in all bioassays. The absorbance of untreated cells in culture media containing $0.5 \%$ DMSO (control) was used as $100 \%$ cell viability, and the percentage of dead cells in each treatment was estimated by comparison with the untreated control. 
For all assays, $\mathrm{IC}_{50} / 24 \mathrm{~h}$ values (based on cell counting, MTT data or infection index values) and doseresponse curves were generated using the CompuSyn software (ComboSyn Inc., Paramus, NJ, USA), and statistical analysis was performed in Excel. For all assays, the fraction of affected cells $(\mathrm{Fa})$ was calculated relative to the untreated control (treated/untreated ratio).

To test the activity of $\mathrm{PaEO}$ on epimastigote forms, these cells were seeded into 96 -well plates $\left(5 \times 10^{6}\right.$ cells/ well) in LIT medium, and treated for $24 \mathrm{~h}$ at $28^{\circ} \mathrm{C}$ with $\mathrm{PaEO}$ at the final concentrations of $9,18,37,75,150$ and $300 \mu \mathrm{g} / \mathrm{mL}$. As a control, BZ (at $6.25,12.5,25$ or $50 \mu \mathrm{g} /$ $\mathrm{mL}$ ) or LIT medium with $0.5 \%$ DMSO (negative control) were used. Cell viability was assessed by the MTT assay (see "MTT assay").

$P a$ EO activity assays with cell-derived trypomastigotes were performed at $28^{\circ} \mathrm{C}$ and $4^{\circ} \mathrm{C}$. Cell-derived trypomastigotes $\left(5 \times 10^{7}\right.$ cells/well) were seeded in 96-well plates with DMEM, and treated with $\mathrm{PaEO}$ or $\mathrm{BZ}$ at the final concentrations $1,10,50$ and $100 \mu \mathrm{g} / \mathrm{mL}$, or with gentian violet ( 1 and $25 \mu \mathrm{M}$; for $4^{\circ} \mathrm{C}$ experiments only). Untreated cells were used as a negative control. For treatments at $28^{\circ} \mathrm{C}$, plates were incubated at this temperature for $24 \mathrm{~h}$. Then, each well was diluted 1:10 with $10 \%$ formaldehyde in PBS and cells were counted in a hemocytometer. For treatment at $4^{\circ} \mathrm{C}$, plates were incubated at this temperature for $24 \mathrm{~h}$ and then subjected to the MTT assay (see "MTT assay"). Due to the small size of trypomastigotes, the MTT reagent was used at the concentration of $1 \mathrm{mg} / \mathrm{mL}$ ( 2.5 fold less than that used for epimastigotes), which improved the correlation between the number of viable cells and the optical density (not shown). The major constituents of $P$. aduncum EO linalool and nerolidol (both from Sigma, St. Louis, MO, USA) - were also tested (at the concentrations of 100, 250, 500 or $1000 \mathrm{ng} / \mathrm{mL}$ ) against $T$. cruzi cell-derived trypomastigotes at $4^{\circ} \mathrm{C}$, as described above.

To test $P a \mathrm{EO}$ activity on metacyclic trypomastigotes, these cells were plated in 96 -well plates $\left(5 \times 10^{6}\right.$ cells/well) with TAU3AAG medium, and treated with EO at the final concentrations of $1,10,50$ or $100 \mu \mathrm{g} / \mathrm{mL}$, for $24 \mathrm{~h}$ at $28^{\circ} \mathrm{C}$. Then, each well was diluted at 1:10 with $10 \%$ formaldehyde in PBS, and cells were counted in a hemocytometer.

To test $P a \mathrm{EO}$ activity against intracellular amastigotes, Vero cells were seeded in 24 -well plates $\left(2 \times 10^{4}\right.$ cells/well) in DMEM (Sigma-Aldrich), and allowed to adhere for $24 \mathrm{~h}$. Then, cell-derived trypomastigotes were added to each well (1:10 ratio of cells to parasites), incubated for $3 \mathrm{~h}$, and non-internalised parasites were removed by washing with PBS. Infected cultures were incubated for $24 \mathrm{~h}$ (at $37^{\circ} \mathrm{C}, 5 \% \mathrm{CO}_{2}$ ), and then the culture medium was replaced with RPMI-1640 containing $P a \mathrm{EO}$ or BZ at final concentrations between 1 and $100 \mu \mathrm{g} / \mathrm{mL}$ (total volume of $1 \mathrm{~mL} /$ well), and plates were incubated for $24 \mathrm{~h}$, at $37^{\circ} \mathrm{C}\left(5 \% \mathrm{CO}_{2}\right)$. Treated cells were fixed with methanol, stained with Giemsa, and the inhibitory effect on intracellular amastigotes was estimated by counting (a) the number of infected cells, and (b) the number of amastigotes per cell, in 100 cells/wells, from random light microscopy images. These data were used to calculate the infection index (II) for each tested concentration (II $=\%$ infected cells $\mathrm{x}$ number of amastigotes per cell).
MTT assay - After drug treatments, MTT solution (10 $\mathrm{mg} / \mathrm{mL}$ in PBS) was added to each well for a final concentration of $2.5 \mathrm{mg} / \mathrm{mL}$ (or $1 \mathrm{mg} / \mathrm{mL}$ for trypomastigotes). Plates were incubated for $3 \mathrm{~h}$ at $28^{\circ} \mathrm{C}$ in the dark, centrifuged for $10 \mathrm{~min}$ at $475 \mathrm{~g}$ and the supernatant was removed (by quick plate reversal). Then, $20 \mu \mathrm{L}$ SDS was added to each well, followed by incubation for $1 \mathrm{~h}$ at $28^{\circ} \mathrm{C}$, after which $80 \mu \mathrm{L}$ DMSO was added to each well and incubated for a further $1 \mathrm{~h}$ at $28^{\circ} \mathrm{C}$. Finally, the residual material was removed with the aid of a toothpick, and sample absorbance (at $550 \mathrm{~nm}$ ) was read in an EL800 microplate reader (Biotek, Winooski, VT, USA). Dose-response curves were produced using the CompuSyn software, which was also used to calculate $\mathrm{IC}_{50} / 24$ values.

Cytotoxicity - Vero cells were seeded in 96-well plates $\left(2 \times 10^{4}\right.$ cells/well) with RPMI-1640 medium and cultivated for $24 \mathrm{~h}$ at $37^{\circ} \mathrm{C}\left(5 \% \mathrm{CO}_{2}\right)$. Cells were incubated for a further $24 \mathrm{~h}$ in the presence of $P a \mathrm{EO}(9,18,37$, $75,150$ or $300 \mu \mathrm{g} / \mathrm{mL})$, linalool $/$ nerolidol $(30,60,125$, 250 or $500 \mathrm{ng} / \mathrm{mL})$, BZ $(1,10,100$ or $1000 \mu \mathrm{g} / \mathrm{mL})$ or gentian violet $(100,500$ or $1000 \mu \mathrm{g} / \mathrm{mL})$. Then, plates were subjected to the MTT assay as described above (see "MTT assay"), and MTT data were used to calculate $50 \%$ cytotoxicity $\left(\mathrm{CC}_{50} / 24 \mathrm{~h}\right)$ values. Plates were examined in an inverted microscope every $12 \mathrm{~h}$, to evaluate monolayer integrity (confluence and adhesion).

To analyse cytotoxicity on red blood cells (RBCs) at $4^{\circ} \mathrm{C}$, human erythrocytes were obtained from $10-\mathrm{mL}$ blood samples $(\mathrm{O}+)$, from a healthy volunteer donor, as previously described (Izumi et al. 2012). After collection, blood was defibrillated and then washed with a sterile 'saline-glucose' solution $(0.85 \% \mathrm{NaCl} / 5 \%$ glucose). The final pellet was diluted in saline-glucose and centrifuged for $5 \mathrm{~min}$ at $1400 \mathrm{~g}$. The supernatant was discarded and the pellet of RBCs was diluted in salineglucose, for a final concentration of $6 \%$. Then, RBCs were seeded in 96 -well plates ( $3 \% \mathrm{RBCs} /$ well) and treated with $\mathrm{EO}(0.1,0.2,0.4,0.8,1.6$ or $3.2 \mathrm{mg} / \mathrm{mL})$, for $5 \mathrm{~h}$, at $4^{\circ} \mathrm{C}$. Negative control samples represented untreated RBCs diluted in saline-glucose. After treatment, plates were centrifuged at $1027 \mathrm{~g}$ for $2 \mathrm{~min}$, and $100 \mu \mathrm{L}$ of supernatant from each well were transferred to a new plate and analysed (at $550 \mathrm{~nm}$ ) in an EL800 microplate reader (Biotek, Winooski, VT, USA).

Cytotoxicity $\left(\mathrm{CC}_{50}\right)$ values were calculated using Excel, and selectivity index (SI) values were calculated as the ratio between the $\mathrm{CC}_{50} / 24 \mathrm{~h}$ (for Vero cells or RBCs) and $\mathrm{IC}_{50} / 24 \mathrm{~h}$ values.

Flow cytometry - For flow cytometry analysis, epimastigotes were seeded into 96 -well plates $\left(5 \times 10^{6}\right.$ cells/ well) in LIT medium and treated with $P a \mathrm{EO}$ at a concentration corresponding to the $\mathrm{IC}_{50} / 24 \mathrm{~h}$, for $24 \mathrm{~h}$. Negative control cells were kept untreated. Then, cells were washed twice in PBS (with centrifugation at $7000 \mathrm{~g}$ for $2 \mathrm{~min}$ ) and transferred to plastic flow cytometry tubes $(300 \mu \mathrm{L} /$ tube).

To evaluate the effect of $P a \mathrm{EO}$ on the T. cruzi cell cycle, $1 \mathrm{~mL}$ of $10 \mu \mathrm{g} / \mathrm{mL}$ propidium iodide diluted in 5\% NP40, with $20 \mu \mathrm{g} / \mathrm{mL}$ RNAse (Qubit RNA HS Assay Kit, ThermoFisher Scientific, Waltham, MA, USA) was added to each tube, and samples were incubated for $20 \mathrm{~min}$ at $28^{\circ} \mathrm{C}$. 
To evaluate the effect of $P a \mathrm{EO}$ on $T$. cruzi mitochondrial membrane potential, rhodamine 123 (final concentration $10 \mu \mathrm{g} / \mathrm{mL}$ ) was added to cultures after $P a \mathrm{EO}$ treatment, and cells were incubated for $20 \mathrm{~min}$ at $28^{\circ} \mathrm{C}$, before PBS washing and transfer to flow cytometry tubes. Culture treatment with $10 \mu \mathrm{M} \mathrm{CCCP}$ (carbonyl cyanide 3-clorophenylhydrazone, Sigma Aldrich, St. Louis, MO, USA) after the rhodamine incubation was used as a positive control.

Flow cytometry samples were analysed in a FACS Canto II (Becton-Dickinson, San Jose, CA, USA) flow cytometer (20,000 events/sample; $488 \mathrm{~nm}$ excitation and $585 / 42 \mathrm{~nm}$ emission for propidium iodide; 488 excitation and 530/30 emission for rhodamine 123), and data analysis was performed in FlowJo (Treestar Software, Ashland, OR, USA). Statistical analysis was performed by one-way analysis of variance (ANOVA), using GraphPad Prism 5.01 software.

\section{RESULTS}

Cell-derived T. cruzi trypomastigotes are sensitive to $P a E O$ - The EO of $P$. aduncum - a pepper species that has already yielded anti-trypanocidal extracts and molecules - had not been tested for its biological activity against $T$. cruzi. Thus, we tested the purified $P a \mathrm{EO}$ against different T. cruzi developmental forms, namely epimastigotes (axenically grown insect forms), cell-derived amastigotes and trypomastigotes (produced in monolayers of mammalian host cells) and infective metacyclic trypomastigotes (differentiated, by metacyclogenesis in vitro, from epimastigotes) (Fig. 1). As a reference drug, we used BZ, the current first-line for Chagas disease.

Cell-derived trypomastigotes were more sensitive to $\mathrm{PaEO}\left(\mathrm{IC}_{50} / 24 \mathrm{~h}\right.$ at $\left.28^{\circ} \mathrm{C}=2.8 \mu \mathrm{g} / \mathrm{mL}\right)$ than to $\mathrm{BZ}$ $\left(\mathrm{IC}_{50} / 24 \mathrm{~h}=16.1 \mu \mathrm{g} / \mathrm{mL}\right.$ ) (Table I). Metacyclic trypomastigotes were also sensitive to $P$. aduncum EO, with $\mathrm{IC}_{50} / 24 \mathrm{~h}$ values for $P a \mathrm{EO}$ and $\mathrm{BZ}$ of $12.1 \mu \mathrm{g} / \mathrm{mL}$ and 0.3 $\mu \mathrm{g} / \mathrm{mL}$, respectively.

T. cruzi epimastigotes were incubated for $24 \mathrm{~h}$ at $28^{\circ} \mathrm{C}$ with different concentrations of $\mathrm{PaEO}$ or $\mathrm{BZ}$, and doseresponse curves estimated the $\mathrm{IC}_{50} / 24 \mathrm{~h}$ values as $84.7 \mu \mathrm{g} /$ $\mathrm{mL}$ for $P a \mathrm{EO}$ and $14.7 \mu \mathrm{g} / \mathrm{mL}(45 \mu \mathrm{M})$ for BZ (Table I).

Blood transfusion is an important route for Chagas disease transmission, due to the presence of infective trypomastigotes in blood from infected donors. Thus, we tested the sensitivity of cell-derived trypomastigotes to $P a \mathrm{EO}$ at $4^{\circ} \mathrm{C}$, the temperature used for red blood storage in blood banks. Incubation at $4^{\circ} \mathrm{C}$ led to inactivation of $\mathrm{BZ}$, as evidenced by the presence of clumps of crystalline material in the medium (likely representing BZ agglutination), and by the absence of trypanosome morphological damage or motility loss, as assessed by light microscopy observation (not shown). Therefore, for the experiments at $4^{\circ} \mathrm{C}$ we used gentian violet as a control, since this drug can be used to treat blood potentially infected with Chagas disease (Ramirez et al. 1995). Importantly, cell-derived trypomastigotes were 6,500 times more sensitive to $P$. aduncum $\mathrm{EO}\left(\mathrm{IC}_{50} / 24 \mathrm{~h}=3.8 \mu \mathrm{g} / \mathrm{mL}\right)$ than to gentian violet $\left(\mathrm{IC}_{50} / 24 \mathrm{~h}=24,700 \mathrm{mg} / \mathrm{mL}\right)$.

To estimate $P a$ EO cytotoxicity, we performed cytotoxicity assays in uninfected Vero cells at $37^{\circ} \mathrm{C}$ (Table II), and also in human erythrocytes (RBCs) at $4^{\circ} \mathrm{C}$ (to mimic red blood cell storage conditions in blood banks). $\mathrm{PaEO}$ was more cytotoxic to Vero cells than $\mathrm{BZ}$, with a $\mathrm{CC}_{50} / 24 \mathrm{~h}$ of $42.8 \mu \mathrm{g} / \mathrm{mL}$, compared with $1,021 \mathrm{mg} / \mathrm{mL}$ for BZ. At the treatment temperature of $4^{\circ} \mathrm{C}$, gentian violet also exhibited lower cytotoxicity to RBCs $\left(\mathrm{CC}_{50} / 24\right.$ $\mathrm{h}=71.4 \mathrm{mg} / \mathrm{mL})$ than $P a \mathrm{EO}\left(\mathrm{CC}_{5} / 24 \mathrm{~h}=351.6 \mu \mathrm{g} / \mathrm{mL}\right)$.

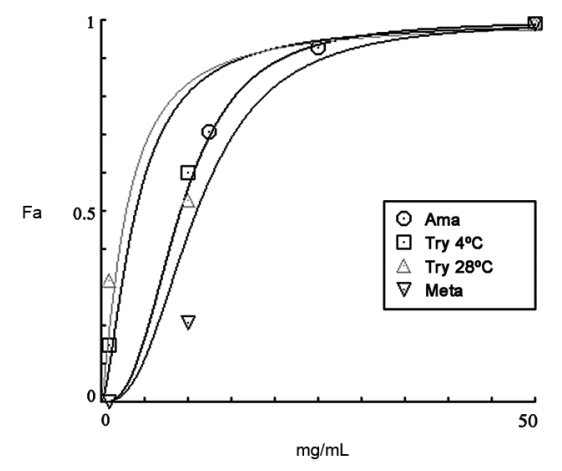

Fig. 1: effect of Piper aduncum essential oil (PaEO) on Trypanosoma cruzi. Dose-response curves showing the inhibitory effect of $\mathrm{PaEO}$ on $T$. cruzi metacyclic trypomastigotes (meta), cell-derived trypomastigotes (try) and intracellular amastigotes (ama). Fa $=$ Fraction of affected cells (ratio to untreated control).

\section{TABLE I}

Inhibitory effect $\left(\mathrm{IC}_{50} / 24 \mathrm{~h}\right)$ and selectivity index (SI) of Piper aduncum essential oil (PaEO) for the treatment of different Trypanosoma cruzi developmental forms, compared with benznidazole (BZ)

\begin{tabular}{lcccc}
\hline & \multicolumn{2}{c}{$\mathrm{IC}_{50} / 24 \mathrm{~h}(\mu \mathrm{g} / \mathrm{mL})$} & \multicolumn{2}{c}{ Selectivity index (SI) } \\
\cline { 2 - 5 } & $P a \mathrm{EO}$ & $\mathrm{BZ}$ & $P^{\mathrm{a}}$ & $\mathrm{BZ}^{\mathrm{b}}$ \\
\hline Cell-derived trypomastigotes $\left(28^{\circ} \mathrm{C}\right)$ & 2.8 & 16.1 & 15.3 & 63.4 \\
Cell-derived trypomastigotes $\left(4^{\circ} \mathrm{C}\right)$ & 3.8 & $\mathrm{ND}$ & 11.3 & $\mathrm{ND}$ \\
Metacyclic trypomastigotes $\left(28^{\circ} \mathrm{C}\right)$ & 12.1 & 0.3 & 3.5 & $3,646.4$ \\
Epimastigotes $\left(28^{\circ} \mathrm{C}\right)$ & 84.7 & 14.7 & 0.5 & 69.4 \\
Amastigotes $\left(37^{\circ} \mathrm{C}\right)$ & 9 & 0.8 & 4.7 & $1,276.2$ \\
\hline
\end{tabular}

$a: \mathrm{SI}=\mathrm{CC}_{50} P a \mathrm{EO}$ on Vero cells $(42.8 \mu \mathrm{g} / \mathrm{mL}) / \mathrm{IC}_{50} P a \mathrm{EO} ; b$ : $\mathrm{SI}=\mathrm{CC}_{50}$ BZ on Vero cells $(1021 \mu \mathrm{g} / \mathrm{mL}) / \mathrm{IC}{ }_{50}$ BZ; ND: not done. 
Selectivity index (SI) analysis - representing the ratio between $\mathrm{IC}_{50} / 24 \mathrm{~h}$ and $\mathrm{CC}_{50} / 24 \mathrm{~h}$ values - indicates that $\mathrm{PaEO}$ is particularly selective towards cell-derived $T$. cruzi trypomastigotes $(\mathrm{SI}=15.3$ and 11.3 , for treatments with Vero cells at $28^{\circ} \mathrm{C}$ and $4{ }^{\circ} \mathrm{C}$, respectively; Table I). Importantly, at the treatment temperature of $4^{\circ} \mathrm{C}, \mathrm{PaEO}$ was more selective towards this form of the parasite than gentian violet $(\mathrm{SI}=2.9)$.

PaEO inhibits effectively the intracellular survival/ replication of T. cruzi amastigotes - To test the effect of $P a \mathrm{EO}$ on amastigotes, Vero cells were infected with trypomastigotes and, after $24 \mathrm{~h}$ (when trypomastigotes had differentiated into amastigotes), the infected cultures were incubated with different concentrations of $P a \mathrm{EO}$ (or $\mathrm{BZ}$, as a reference). $P a \mathrm{EO}$ at the concentration of $12.5 \mu \mathrm{g} /$ $\mathrm{mL}$ decreased the $T$. cruzi amastigote infection index by $71.5 \%$, similarly to $10 \mu \mathrm{g} / \mathrm{mL}$ BZ $(81.3 \%$ decrease; Table III), showing that $P a \mathrm{EO}$ is as effective as the standard drug used for Chagas disease treatment, at this concentration. However, BZ was much more efficient than $P a \mathrm{EO}$ at inhibiting intracellular amastigote replication and survival, with an $\mathrm{IC}_{50} / 24 \mathrm{~h}$ (calculated from infection index data) of $0.8 \mu \mathrm{g} / \mathrm{mL}$, compared with $9 \mu \mathrm{g} / \mathrm{mL}$ for $P a \mathrm{EO}$ (Table I). Also, strong cytotoxic effects occurred after treatment with $100 \mu \mathrm{g} / \mathrm{mL} P a \mathrm{EO}$ (data not shown).

To examine the mechanism of action of $P a \mathrm{EO}$ on T. cruzi, epimastigotes were incubated for $24 \mathrm{~h}$ at $28^{\circ} \mathrm{C}$ with the $\mathrm{EO}$ and then subjected to cell cycle analysis by labeling with propidium iodide, or were labelled with Rhodamine-123, to analyse the effect of $\mathrm{PaEO}$ on the mitochondrial membrane potential. Although epimastigotes do not have direct medical importance, this life cycle form is ideal for in vitro analysis, because they can be cultivated easily in axenic medium.

Treatment of epimastigotes with $\mathrm{PaEO}$ at the $\mathrm{IC}_{50} / 24$ $\mathrm{h}$ did not alter significantly the number of cells in the G1 phase of the cell cycle, but there was a significant decrease in the number of cells in G2 (Fig. 2A-B). Labeling with rhodamine-123 showed that the $P a \mathrm{EO}$ decreased the mitochondrial membrane potential of nearly $98 \%$ of the tested epimastigotes (Fig. 2C-D), indicating a possible target of this compound.

Chemical composition analysis by gas chromatography/mass spectrometry (GC-MS) showed that the main constituents of the $P a \mathrm{EO}$ used in this study are nerolidol $(25.22 \%)$ and linalool (13.42\%) (Table IV). Aside from these two main constituents, $\mathrm{PaEO}$ contained several minor components (each accounting for $\sim 1-5 \%$ of the total area; Table IV). Therefore, we tested the activities of linalool and nerolidol against cell-derived trypomastigotes at $4^{\circ} \mathrm{C}$ (for $24 \mathrm{~h}$ ), because the activity of $\mathrm{PaEO}$ against this developmental form appeared to be particularly promising (Table I). Linalool had clear trypanocidal activity, with an $\mathrm{IC}_{50} / 24 \mathrm{~h}$ of $306 \mathrm{ng} / \mathrm{mL}$ at $4^{\circ} \mathrm{C}$ (Table II), indicating that this compound is approximately 52 times more effective against cell-derived trypanosomes than $\mathrm{BZ}$ at $28^{\circ} \mathrm{C}$ (Table I). Cytotoxicity tests on Vero cells (at $4^{\circ} \mathrm{C}$ ) demonstrated that linalool was cytotoxic, however, with a $\mathrm{CC}_{50} / 24 \mathrm{~h}$ of $823.6 \mathrm{ng} / \mathrm{mL}$, which resulted in a selectivity index (SI) for the treatment of cell-derived trypomastigotes at $4^{\circ} \mathrm{C}$ of 2.69 (Table II).

TABLE II

Inhibitory effect $\left(\mathrm{IC}_{50} / 24 \mathrm{~h}\right.$, in $\left.\mu \mathrm{g} / \mathrm{mL}\right)$ and cytotoxicity $\left(\mathrm{CC}_{50} / 24 \mathrm{~h}\right.$, in $\left.\mu \mathrm{g} / \mathrm{mL}\right)$ of Piper aduncum essential oil (PaEO), gentian violet and linalool for Trypanosoma cruzi cell-derived trypomastigotes, red blood cells $\left(\mathrm{RBCs}\right.$, at $\left.4^{\circ} \mathrm{C}\right)$ and Vero cells $\left(\right.$ at $\left.37^{\circ} \mathrm{C}\right)$

\begin{tabular}{lccccc}
\hline & T. cruzi & RBCs & Selectivity index (SI) - & Vero cells & \multicolumn{2}{c}{ Selectivity index (SI) - } \\
& $\mathrm{IC}_{50} / 24 \mathrm{~h}$ & $\mathrm{CC}_{50} / 24 \mathrm{~h}$ & $\mathrm{RC}_{50} / 24 \mathrm{~h}$ & Vero cells \\
\hline PaEO & 3.8 & 351.6 & 92.5 & 42.8 & 11.2 \\
Linalool & 0.31 & $7,341.6$ & 23,990 & 0.87 & 2.7 \\
Gentian Violet & 24,700 & $>70,000$ & $>2.8$ & 71,400 & 2.9 \\
\hline
\end{tabular}

TABLE III

Effect of 24 h-treatment with Piper aduncum essential oil (PaEO) on Trypanosoma cruzi intracellular amastigotes in Vero cells, compared with benznidazole (BZ)

\begin{tabular}{|c|c|c|c|c|c|}
\hline & Concentration $(\mu \mathrm{g} / \mathrm{mL})$ & Infected cells $(\%)$ & Amastigotes per cell & Infection index (II) & II decrease \\
\hline \multirow[t]{4}{*}{$P a \mathrm{EO}$} & 0 & 79.1 & 7.1 & 562.1 & 0 \\
\hline & 12.5 & 54.6 & 2.9 & 160.1 & 71.5 \\
\hline & 50 & 32.5 & 0.4 & 12.7 & 97.7 \\
\hline & 100 & 0 & 0 & 0 & 100 \\
\hline \multirow[t]{3}{*}{$\mathrm{BZ}$} & 0 & 87.3 & 11.5 & 1003.7 & 0 \\
\hline & 10 & 74.9 & 2.5 & 187.2 & 81.3 \\
\hline & 50 & 0.4 & 0.9 & 0.3 & 99.9 \\
\hline
\end{tabular}



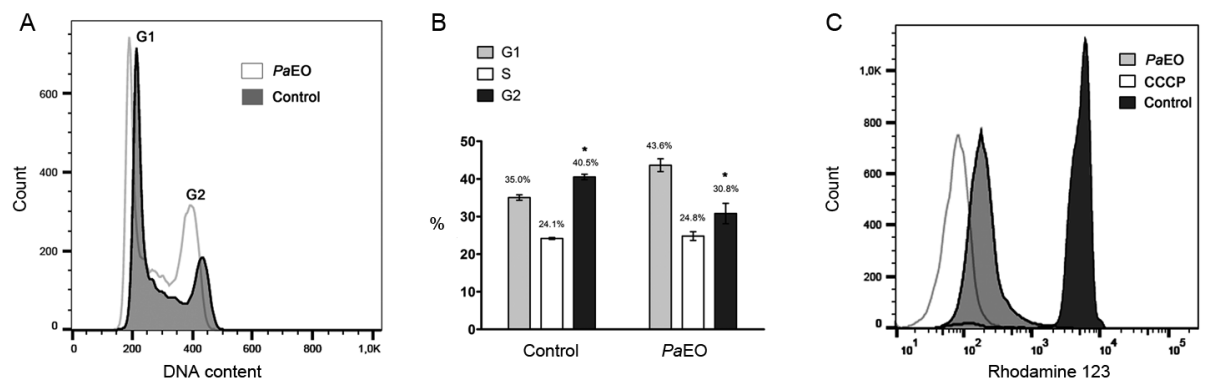

D

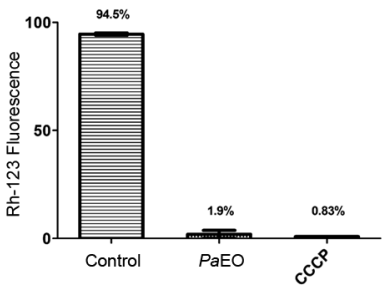

Fig. 2: effect of Piper aduncum essential oil (PaEO) on Trypanosoma cruzi epimastigotes, as analysed by flow cytometry. (A-B) Cell cycle analysis. Epimastigotes were treated for $24 \mathrm{~h}$ at $28^{\circ} \mathrm{C}$ with the $\mathrm{IC}_{50} / 24 \mathrm{~h}$ value of $P a \mathrm{EO}$ and then incubated with propidium iodide (PI). (A) Histograms of the PI-stained cell populations; (B) mean number of cells in each cell cycle stage. *: $p<0.05$. (C-D) Mitochondrial membrane potential analysis. Epimastigotes were kept for $24 \mathrm{~h}$ at $28^{\circ} \mathrm{C}$ with the $\mathrm{IC}_{50} / 2 \mathrm{~h}$ value of $\mathrm{PaEO}$ and then incubated with Rhodamine-123. CCCP (carbonyl cyanide 3-clorophenylhydrazone): positive control. (C) Histograms of the Rhodamine-123-stained populations; (D) percentage of labelled cells after each treatment.

\section{TABLE IV}

Chemical composition of Piper aduncum essential oil ( $\mathrm{PaEO})$, as assessed by gas chromatography/mass spectrometry (GC/MS)

\begin{tabular}{lccc}
\hline Constituent & Retention time & Area & Area (\%) \\
\hline Nerolidol & 31.13 & 18000000 & 25.22 \\
Linalool & 11.83 & 9336350 & 13.42 \\
Spatulenol & 31.77 & 4374871 & 6.29 \\
$\beta$-ocimene & 9.76 & 3237239 & 4.65 \\
2-cycloexen-1-ol & 25.48 & 3092676 & 4.44 \\
Germacrene D & 27.99 & 2804545 & 4.03 \\
$\beta$-chamigrene & 28.59 & 2788502 & 4.01 \\
E- $\beta$-farnesene & 26.95 & 2509366 & 3.61 \\
$\gamma$-cadinene & 29.37 & 2439762 & 3.51 \\
$\alpha$-epi-muurolol & 34.25 & 1893537 & 2.72 \\
$\alpha$-bisabolol oxide & 34.75 & 1867181 & 2.68 \\
$\alpha$-ocimene & 9.36 & 1807180 & 2.6 \\
Turmerone & 32.49 & 1437434 & 2.07 \\
Caryophyllene oxide & 31.98 & 1248458 & 1.79 \\
$\alpha$-copaene & 23.65 & 1169184 & 1.68 \\
Viridiflorol & 33.04 & 1117593 & 1.61 \\
$\beta$-pinene & 7.5 & 988059 & 1.42 \\
$\alpha$-cadinol & 34.43 & 975559 & 1.4 \\
$\alpha$-cubebene & 24.16 & 884691 & 1.27 \\
$\delta$-cadineme & 29.5 & 854201 & 1.23 \\
$\alpha$-pinene & 6.2 & 680357 & 0.98 \\
Safrole & 19.94 & 640257 & 0.92 \\
\hline
\end{tabular}

In contrast to linalool, nerolidol had no appreciable trypanocidal activity against cell-derived trypomastigotes $\left(4^{\circ} \mathrm{C}, 24 \mathrm{~h}\right)$ at concentrations between $100 \mathrm{ng} / \mathrm{mL}$ and $1 \mu \mathrm{g} / \mathrm{mL}$, as assessed by light microscopy observation and MTT assays (data not shown). Also, nerolidol did not affect the integrity of Vero cell monolayers, after treatment for $24 \mathrm{~h}$ with the highest concentration used $(1 \mu \mathrm{g} / \mathrm{mL}$; not shown). These data indicate that the trypanocidal effect of $\mathrm{PaEO}$ was due to linalool.

\section{DISCUSSION}

The microbicidal activity of EOs - against fungi, bacteria and viruses - is used primarily as a defense to ensure plant survival (Bakkali et al. 2008). A number of EOs are active against $T$. cruzi epimastigotes and trypomastigotes (Santoro et al. 2007a, b, Escobar et al. 2010, Borges et al. 2012, Silva et al. 2013, Azeredo et al. 2014) and recent studies showed that EOs from different pepper species (Piper spp.) have promising leishmanicidal (Monzote et al. 2010) and trypanocidal (Esperandim et al. 2013) activities. Nevertheless, the EO of the pepper species P. aduncum - whose extracts have clear trypanocidal activity had not been tested previously against $T$. cruzi.

In the present study, we show that $T$. cruzi trypomastigotes and amastigotes are sensitive to $P a \mathrm{EO}$ at concentrations of 2.8 to $12.1 \mu \mathrm{g} / \mathrm{mL}$ (Table I). Importantly, the highly infective cell-derived trypomastigote forms which can be found in contaminated blood from Chagas disease patients - were particularly sensitive to $P a \mathrm{EO}$, with an $\mathrm{IC}_{50} / 24 \mathrm{~h}$ of $2.8 \mu \mathrm{g} / \mathrm{mL}$.

Also, treatment of T. cruzi trypomastigotes and human erythrocytes with $\mathrm{PaEO}$ at $4^{\circ} \mathrm{C}$ resulted in an excellent selectivity index $(\mathrm{SI}=92.5)$ (Table II). The first desirable property of a promising drug candidate is an SI $>50$ (Romanha et al. 2010); thus, $\mathrm{PaEO}$ (or its main constituent linalool) is a promising alternative for further testing on blood/blood cells, under thermal conditions of red blood cells storage $\left(4^{\circ} \mathrm{C}\right)$, in order to obtain derivatives effective at eliminating T. cruzi in blood bank samples.

In our tests with cell-derived trypomastigotes at $4^{\circ} \mathrm{C}$ the use of BZ for $24 \mathrm{~h}$ had no effect against the parasite (not shown). The incomplete trypanocidal effect of BZ at $4^{\circ} \mathrm{C}$ can lead to Chagas disease transmission via transfusion of contaminated blood (Martin et al. 2014). Gentian violet was the reference drug of choice in our tests at $4^{\circ} \mathrm{C}$, because it can be used to control T. cruzi infection in blood banks (Ramirez et al. 1995). However, the prophylaxis alternative with gentian violet produces side effects, such as staining in the mucosa and erythrocyte agglutination (Docampo \& Moreno 1990).

In this study, most testing was performed for $24 \mathrm{~h}$, to minimise the effects of nutrient starvation and toxicity 
due to parasite lysis. We believe that these conditions are closer to those found in the mammalian host, where toxin waste is eliminated through the bloodstream. Our data with BZ differ from that reported in other studies, where this drug was often tested for $72 \mathrm{~h}$, yielding lower $\mathrm{IC}_{50}$ values (Franklim et al. 2013, Hamedt et al. 2014). To date, no standard conditions for drug testing against $T$. cruzi have been defined. Therefore, differences in parasite strains, incubation times and temperatures and culture media may all account for variations observed in experimental drug testing, and are likely to delay drug development for Chagas disease treatment (Andrade et al. 1985).

Mitochondrial membrane potential evaluation of epimastigotes by flow cytometry demonstrated that $\mathrm{PaEO}$ decreased the mitochondrial membrane potential of $\sim 98 \%$ of the treated cells, with similar results obtained with the positive control with CCCP. Therefore, $\mathrm{PaEO}$ may be acting on the parasite mitochondrion. Accordingly, it has been already shown that other natural products induce depolarisation of mitochondrial membrane in Trypanosomatids such as T. cruzi and Leishmania (Inacio et al. 2012, Caleare et al. 2013, Ribeiro et al. 2013, Takahashi et al. 2013, Aliança et al. 2014, CorpasLópez et al. 2016, Sülsen et al. 2016).

EOs may affect different cellular targets, due to variations in their molecular composition. As they contain lipophilic molecules, the mechanism of action of EOs involves breakage and/or crossing of the plasma membrane (Knobloch et al. 1989, Sikkema et al. 1994). While our data showed that the $\mathrm{PaEO}$ may target the mitochondrion, we can not exclude the possibility that mitochondrial damage is a secondary effect of drug treatment.

The $P a \mathrm{EO}$ used in this work had nerolidol (25.22\%) and linalool (13.42\%) as its main constituents. GC-MS analysis of the essential oil of P. aduncum in other studies showed that it can yield four major constituents: (a) dillapiole, at $79.9-86.9 \%$ (Almeida et al. 2009); (b) nerolidol, at 79.2-82.5\% (Oliveira et al. 2006); (c) cineole, at 54\% (Oliveira et al. 2013), and (d) linalool, at 31$41 \%$ (Navickiene et al. 2006). This variation in composition may be explained by the collection of plants from different regions, and which are exposed to different environmental factors. Thus, to minimise $\mathrm{EO}$ composition variation between studies, the collected material should always come from the same location. The best thermal storage conditions for $P$. aduncum EO is $20^{\circ} \mathrm{C}$ (for up to six months), without loss of regenerative capacity (da Silva \& Scherwinski-Pereira 2011).

In this work we show that nerolidol - the major $P a \mathrm{EO}$ component - failed to affect significantly the cell-derived trypomastigote form of $T$. cruzi, at $4^{\circ} \mathrm{C}$, even at the concentration of $1 \mu \mathrm{g} / \mathrm{mL}$. In contrast, linalool had potent trypanocidal effect against this parasite form, with an $\mathrm{IC}_{50} / 24$ $\mathrm{h}$ of $306 \mathrm{ng} / \mathrm{mL}$. These results show that the major component of an EO may not always be responsible for the lytic activity. Interestingly, incubation of linalool with $T$. cruzi blood trypomastigotes ( $\mathrm{Y}$ strain) resulted in an $\mathrm{IC}_{50} / 24 \mathrm{~h}$ value of $264 \mu \mathrm{g} / \mathrm{mL}$ (Santoro et al. 2007b), indicating that trypomastigote forms of different origin (blood, cell culture or in vitro differentiation) and from different strains may differ in their susceptibility to EO derivatives.
Our cytotoxicity tests in Vero cells showed that cell monolayers remained intact after nerolidol treatment, without clear changes or toxic effects, even at the concentration of $1 \mu \mathrm{g} / \mathrm{mL}$. However, linalool was cytotoxic, with $\mathrm{CC}_{50} / 24$ of $823.6 \mathrm{ng} / \mathrm{mL}$, indicating that the major constituent is not necessarily the one responsible for $\mathrm{EO}$ toxicity towards mammalian cells, as suggested in other studies (Almeida et al. 2009, Oliveira et al. 2013, Liu et al. 2014). Also, linalool was approximately 80,000 times more efficient against cell-derived trypomastigotes at $4^{\circ} \mathrm{C}$ than gentian violet, the drug commonly used to treat possibly contaminated blood bags.

In conclusion, our data indicate that the $P$. aduncum essential oil component linalool is a promising compound for further studies on the trypanocidal treatment of red blood cell bags at $4^{\circ} \mathrm{C}$ prior to transfusion, to prevent $T$. cruzi transmission via this important route. To improve the safety profile of linalool, combinations with less toxic compounds (including benznidazole) should be tested, and linalool could be used as a lead for further drug development.

\section{ACKNOWLEDGEMENTS}

To the Microscopy Center of the Federal University of Paraná (Curitiba, PR, Brazil) and the Rudolph Barth Electron Microscopy Platform of the Oswaldo Cruz Institute/Fiocruz, RJ, Brazil, for use of their electron microscopy facilities.

\section{AUTHORS' CONTRIBUTION}

LHV designed and performed the biological screening experiments (single drug activity assays on Trypanosoma cruzi developmental forms, cytotoxicity, flow cytometry) and drafted the manuscript; JA and MLT were responsible for the Piper aduncum essential oil purification and chemical analysis; MJS and MGC supervised, analysed the data and edited the manuscript.

\section{REFERENCES}

Aliança ASS, dos Anjos KF, Reis TNV, Higino TM, Brelaz-de-Castro $\mathrm{MC}$, Bianco ÉM, et al. The in vitro biological activity of the Brazilian brown seaweed Dictyota mertensii against Leishmania amazonensis. Molecules. 2014; 19(9): 14052-65.

Almeida RR, Souto RN, Bastos CN, Silva MH, Maia JG. Chemical variation in Piper aduncum and biological properties of its dillapiole-rich essential oil. Chem Biodivers. 2009; 6(9): 1427-34.

Alviano DS, Barreto AL, Dias FA, Rodrigues IA, Rosa MS, Alviano $\mathrm{CS}$, et al. Conventional therapy and promising plant-derived compounds against trypanosomatid parasites. Front Microbiol. 2012; 3: 283 .

Andrade V, Andrade SG, Barrai Netto M, Pontes AL, Castro R. Avaliação do comportamento de diferentes cepas do Trypanosoma cruzi na infecção de seis linhagens isogênicas de camundongos. Rev Soc Bras Med Trop. 1985; 18(3): 143-54.

Assal A, Corbi C. Maladie de Chagas et transfusión sanguine: un problème parasitaire émergent dans les pays non endémiques. Transfus Clin Biol. 2011; 18: 286-91.

Azeredo CMO, Santos TG, Maia BHLNS, Soares MJ. In vitro biological evaluation of eight different essential oils against Trypanosoma cruzi, with emphasis on Cinnamomum verum essential oil. BMC Complement Altern Med. 2014; 14: 309.

Bakkali F, Averbeck S, Averbeck D, Idaomar M. Biological effects of essential oils-a review. Food Chem Toxicol. 2008; 46(2): 446-75. 
Batista Jr JM, Lopes AA, Ambrósio DL, Regasini LO, Kato MJ, Bolzani VS, et al. Natural chromenes and chromene derivatives as potential anti-trypanosomal agents. Biol Pharmac Bull. 2008; 31(3): 538-40.

Bern C. Antitrypanosomal therapy for chronic Chagas' disease. N Engl J Med. 2011; 364(26): 2527-34.

Borges AR, Aires JR, Higino TM, Medeiros MGF, Citó AM, Lopes JA, et al. Trypanocidal and cytotoxic activities of essential oils from medicinal plants of Northeast of Brazil. Exp Parasitol. 2012; 132(2): $123-8$.

Caleare AO, Lazarin-Bidóia D, Cortez DA, Ueda-Nakamura T, Dias Filho BP, Silva SO, et al. Trypanocidal activity of 1,3,7-trihydroxy2-(3-methylbut-2-enyl)-xanthone isolated from Kielmeyera coriacea. Parasitol Int. 2013; 62(5): 405-11.

Contreras VT, Salles JM, Thomas N, Morel CM, Goldenberg S. In vitro differentiation of Trypanosoma cruzi under chemically defined conditions. Mol Biochem Parasitol. 1985; 16(3): 315-27.

Corpas-López V, Merino-Espinosa G, Díaz-Sáez V, Morillas-Márquez F, Navarro-Moll MC, Martín-Sánchez J. The sesquiterpene $(-)-\alpha$-bisabolol is active against the causative agents of Old World cutaneous leishmaniasis through the induction of mitochondrialdependent apoptosis. Apoptosis. 2016: 21(10): 1071-81.

Coura JR, de Castro SL. A critical review on Chagas disease chemotherapy. Mem Inst Oswaldo Cruz. 2002; 97(1): 3-24.

da Silva TL, Scherwinski-Pereira JE. In vitro conservation of Piper aduncum and Piper hispidinervum under slow-growth conditions. Pesq Agropec Bras. 2011; 46(4): 384-9.

Docampo R, Moreno SNJ. The metabolism and mode of action of gentian violet. Drug Metab Rev. 1990; 22(2-3): 161-78.

Escobar P, Leal SM, Herrera LV, Martinez JR, Stashenko E. Chemical composition and antiprotozoal activities of Colombian Lippia spp essential oils and their major components. Mem Inst Oswaldo Cruz. 2010; 105(2): 184-90.

Esperandim VR, Ferreira DS, Rezende KCS, Magalhães LG, Souza JM, Pauletti PM, et al. In vitro antiparasitic activity and chemical composition of the essential oil obtained from the fruits of Piper cubeba. Planta Med. 2013; 79(17): 1653-5.

Fishman JA, Rubin RH. Infection in organ-transplant recipients. N Engl J Med. 1998; 338(24): 1741-51.

Flores N, Jiménez IA, Giménez A, Ruiz G, Gutiérrez D, Bourdy G, et al. Antiparasitic activity of prenylated benzoic acid derivatives from Piper species. Phytochemistry. 2009; 70(5): 621-7.

Franklim TN, Freire-de-Lima L, Diniz JNS, Previato JO, Castro RN, Mendonça-Previato L, et al. Design, synthesis and trypanocidal evaluation of novel 1,2,4-triazoles-3-thiones derived from natural piperine. Molecules. 2013; 18(6): 6366-82.

Garcia FP, Lazarin-Bidóia D, Ueda-Nakamura T, Silva SO, Nakamura CV. Eupomatenoid-5 isolated from leaves of Piper regnellii induces apoptosis in Leishmania amazonensis. Evid Based Complement Alternat Med. 2013; 2013: 940531.

Giddings OK, Eickhoff CS, Smith TJ, Bryant LA, Hoft DF. Anatomical route of invasion and protective mucosal immunity in Trypanosoma cruzi conjunctival infection. Infect Immun. 2006; 74(10): 5549-60.

Hamedt AL, Ortiz IC, García-Huertas PA, Sáenz J, Araujo AC, Mattos JC, et al. Cytotoxic, mutagenic and genotoxic evaluation of crude extracts and fractions from Piper jericoense with trypanocidal action. Acta Trop. 2014; 131: 92-7.

Herwaldt BL. Laboratory-acquired parasitic infections from accidental exposures. Clin Microbiol Rev. 2001; 14(4): 659-88.

Houël E, Gonzalez G, Bessière J-M, Odonne G, Eparvier V, Deharo
E, et al. Therapeutic switching: from antidermatophytic essential oils to new leishmanicidal products. Mem Inst Oswaldo Cruz. 2015; 110(1): 106-13.

Inacio JD, Canto-Cavalheiro MM, Menna-Barreto RF, AlmeidaAmaral EE. Mitochondrial damage contribute to epigallocatechin3 -gallate induced death in Leishmania amazonensis. Exp Parasitol. 2012; 132(2): 151-5.

Izumi E, Ueda-Nakamura T, Veiga Jr VF, Pinto AC, Nakamura CV. Terpenes from Copaifera demonstrated in vitro antiparasitic and synergic activity. J Med Chem. 2012; 55(7): 2994-3001.

Jackson Y, Myers C, Diana A, Marti HP, Wolff H, Chappuis F, et al. Congenital transmission of Chagas disease in Latin American immigrants in Switzerland. Emerg Infect Dis. 2009; 15(4): 601-3.

Knobloch K, Pauli A, Iberl B, Weigand H, Weis N. Antibacterial and antifungal properties of essential oil components. J Essent Oil Res. 1989; 1(3): 119-28.

Liu SQ, Scott IM, Pelletier Y, Kramp K, Durst T, Sims SR, et al. Dillapiol: a pyrethrum synergist for control of the Colorado potato beetle. J Econ Entomol. 2014; 107(2): 797-805.

Lopes AA, López SN, Regasini LO, Batista Jr JM, Ambrósio DL, Kato MJ, et al. In vitro activity of compounds isolated from Piper crassinervium against Trypanosoma cruzi. Nat Prod Res. 2008; 22(12): 1040-6.

Martin DL, Goodhew B, Czaicki N, Foster K, Rajbhandary S, Hunter $\mathrm{S}$, et al. Trypanosoma cruzi survival following cold storage: possible implications for tissue banking. PLoS ONE. 2014; 9(4): e95398.

Monzote L, García M, Montalvo AM, Scull R, Miranda M. Chemistry, cytotoxicity and antileishmanial activity of the essential oil from Piper auritum. Mem Inst Oswaldo Cruz. 2010; 105(2): 168-73.

Navickiene HMD, Morandim AA, Alécio AC, Regasini LO, Bergamo DCB, Telascrea M, et al. Composition and antifungal activity of essential oils from Piper aduncum, Piper arboreum and Piper tuberculatum. Quim Nova. 2006; 29(3): 467-70.

Oliveira GL, Cardoso SK, Lara Jr CR, Vieira TM, Guimarães EF, Figueiredo LS, et al. Chemical study and larvicidal activity against Aedes aegypti of essential oil of Piper aduncum L. (Piperaceae). An Acad Bras Cienc. 2013; 85(4): 1227-34.

Oliveira JCS, Dias IJM, Camara CAG, Schwartz MOE. Volatile constituents of the leaf oils of Piper aduncum L. from different regions of Pernambuco (Northeast of Brazil). J Essent Oil Res. 2006; 18(5): 557-9.

Orjala J, Wright AD, Behrends H, Folkers G, Sticher O, Rüegger H, et al. Cytotoxic and antibacterial dihydrochalcones from Piper aduncum. J Nat Prod. 1994; 57(1): 18-26.

Rajão MA, Furtado C, Alves CL, Passos-Silva DG, Moura MB, Schamber-Reis BL, et al. Unveiling benznidazole's mechanism of action through overexpression of DNA repair. Environ Mol Mutagen. 2014; 55(4): 309-21.

Ramirez LE, Lages-Silva E, Pianetti GM, Rabelo RM, Bordin JO, Moraes-Souza H. Prevention of transfusion-associated Chagas' disease by sterilization of Trypanosoma cruzi-infected blood with gentian violet, ascorbic acid, and light. Transfusion. 1995; 35(3): 226-30.

Rassi A, Dias JCP, Marin-Neto JA, Rassi A. Challenges and opportunities for primary, secondary, and tertiary prevention of Chagas' disease. Heart. 2009; 95(7): 524-34.

Regasini LO, Cotinguiba F, Passerini GD, Bolzani VS, Cicarelli RMB, Kato MJ, et al. Trypanocidal activity of Piper arboreum and Piper tuberculatum (Piperaceae). Rev Bras Farmacogn. 2009; 19(1B): 199-203. 
Ribeiro GA, Cunha-Júnior EF, Pinheiro RO, da-Silva SA, CantoCavalheiro MM, da Silva AJ, et al. LQB-118, an orally active pterocarpanquinone, induces selective oxidative stress and apoptosis in Leishmania amazonensis. J Antimicrob Chemother. 2013; 68(4): 789-99.

Romanha AJ, de Castro SL, Soeiro MNC, Lannes-Vieira J, Ribeiro I, Talvani A, et al. In vitro and in vivo experimental models for drug screening and development for Chagas disease. Mem Inst Oswaldo Cruz. 2010; 105(2): 233-8.

Salomon CJ. First century of Chagas' disease: an overview on novel approaches to nifurtimox and benznidazole delivery systems. J Pharm Sci. 2012; 101(3): 888-94.

Santoro GF, Cardoso MG, Guimarães LG, Freire JM, Soares MJ. Anti-proliferative effect of the essential oil of Cymbopogon citratus (DC) Stapf (lemongrass) on intracellular amastigotes, bloodstream trypomastigotes and culture epimastigotes of Trypanosoma cruzi (Protozoa: Kinetoplastida). Parasitology. 2007a; 134(Pt 11): 1649-56.

Santoro GF, Cardoso MG, Guimarães LG, Mendonça LZ, Soares MJ. Trypanosoma cruzi: activity of essential oils from Achillea millefolium L., Syzygium aromaticum L. and Ocimum basilicum L. on epimastigotes and trypomastigotes. Exp Parasitol. 2007b; 116(3): 283-90.
Schmunis GA, Yadon ZE. Chagas disease: a Latin American health problem becoming a world health problem. Acta Trop. 2010; 115(1-2): 14-21.

Sikkema J, Bont JA, Poolman B. Interactions of cyclic hydrocarbons with biological membranes. J Biol Chem. 1994; 269(11): 8022-8.

Silva TB, Menezes LR, Sampaio MF, Meira CS, Guimarães ET, Soares $\mathrm{MB}$, et al. Chemical composition and anti-Trypanosoma cruzi activity of essential oils obtained from leaves of Xylopia frutescens and X. laevigata (Annonaceae). Nat Prod Commun. 2013; 8(3): 403-6.

Sülsen VP, Puente V, Papademetrio D, Batlle A, Martino VS, Frank FM, et al. Mode of action of the sesquiterpene lactones psilostachyin and psilostachyin C on Trypanosoma cruzi. PLoS ONE. 2016; 11(3): e 0150526

Takahashi HT, Britta EA, Longhini R, Ueda-Nakamura T, de Mello JCP, Nakamura CV. Antileishmanial activity of 5-methyl-2,2' : 5',2"-terthiophene isolated from Porophyllum ruderale is related to mitochondrial dysfunction in Leishmania amazonensis. Planta Med. 2013; 79(5): 330-3.

WHO - World Health Organization. Chagas disease (American trypanosomiasis). Fact Sheet 340 [Internet]. Updated March 2016; cited 2016 Aug 08. Available from: http://www.who.int/mediacentre/factsheets/fs340/en/.

Xu WH, Li XC. Antifungal compounds from Piper species. Curr Bioact Compd. 2011; 7(4): 262-7. 